\title{
ARE WE GOOD BEHAVIOURISTS?
}

\author{
Margaret MaRks, M.A. \\ Sub-Department of Speech, Pathology and Audiology, \\ University of the Witwatersrand
}

Behaviour therapy is becoming fashionable. It may be timely for speech pathologists to stand still in the face of the hurtling bandwagon and to say-before we leap on, let us look; what is behaviour therapy? Where do we fit in? Does this bandwagon straddle both fields-speech therapy and psychotherapy? The aim of this article is to pose the question: for speech therapists, is the fashion of behaviour therapy a force or a fad?

We as speech pathologists and speech therapists have always been cognisant of the limitations imposed by the fact that we are not psychotherapists. How do we stand then, vis-a-vis behaviour therapy-this specialised branch of psychotherapy? It could be viewed by some as an insidious enemy, luring us to cross over the fence and assume territory that is not ours, but $I$ would say, rather, that it can be seen as a mediating field showing that the shadowy no-man's-land is rather a both-men's-land, offering firm ground to workers on each side, provided that each knows and understands the region.

Behaviour therapy gives us no more licence to deal with deep-seated emotional problems than we had when the prevailing psychoanalytic ideas set definite limits; instead, it places on us additional responsibilities to those posed by study in our own area: if we are to utilise the techniques of behaviour therapy we must have a thorough knowledge of the underlying theoretical principles. Only when we understand the implications of learning theory will we be able to apply behaviour therapy techniques in our treatment and, carrying this even further, will we be able to devise methods based on a rigorous scientific approach to the problems of the person with defective communication skills. Certain techniques appear tantalisingly simple to carry out-if we utilise them without really understanding all the implications, then we, as speech therapists, are guilty of superficial work, and do much to make the use of behaviour therapy a $\mathrm{fad}$, instead of the force it can be.

What has brought us to this stage, where a consideration of the relationship between the two fields seems inevitable? A survey of our history shows that, while retaining its integrity, speech therapy, covering as it does many areas which overlap into other studies, must needs be influenced by outside trends. Perhaps the changed thinking about the problematic subject of stuttering highlights this best. We can trace the movement from the approach of the elccutionists, with the stress on breathing and on the mechanics of speech; past the psychoanalytic era when stuttering was considered as a fixation at anal or oral level, depend- 
ing, (as one critic has stated) which way one viewed it; through the neurological ideas with the stress on the establishment of cerebral dominance; to the semantic school with its beliefs in re-evaluation, and its product-the 'happy stutterer'.

Now, under the influence of behaviour therapy, we are again concentrating on the actual stuttering behaviour. Some may feel that, in a new guise and protected by a new jargon, we are ready to commit the same sins as an earlier and as well-meaning a generation; can this orientation not give rise to the same unhappy consequences of 'distractive therapy' that resulted from the slow speaking, deep-breathing, rhythmic armswinging approach advocated by therapists of the early nineteen hundreds?

It is necessary to ask-is this new therapy anything more than a series of psuedo-scientific gimmicks? Is behaviour therapy a cob-web cleansing wind, or is it merely a breeze from a new direction, which will blow sporadically and ineffectually, only to end in a whimper? Will students in ten years' time, looking through old clinic reports, discard the late I960's as the years of the 'smarty party'?*

I believe that the relevance of behaviour therapy to speech pathology and therapy is more than this, that it can add new dimensions to our understanding of communication problems, and to their therapy. I have stated elsewhere that speech therapists have always been concerned with the alteration of behaviour and have, even before the term came into existence, been behaviour therapists. ${ }^{*}$ We are attempting to change behaviour, whether it is the behaviour causing the defect, and/or the actual defective behaviour and/or the behaviour resulting from the defect. Once we have accepted this fact, we should use everything in our armoury -and in any other specialist's armoury-which can help us to change undesirable behaviour.

It is impossible, within the scope of this article, to do more than mention some definitions and descriptions of behaviour therapy. It is hoped that brevity will not do it a disservice and that readers will refer to the literature written by the authorities, to realise all the subtleties implicit in the study of this approach to therapy. The writings of Wolpe and Eysenck are basic to an understanding of behaviour therapy; several review articles, such as that of Rachman's in the first issue of Behaviour Research and Therapy, place previous work in historical perspective..$^{5}$ An interesting overview, and comparison with the 'medical model', is given by Ullmann and Krasner in their introduction to the book which they edit."

Briefly, one could phrase the arguments of behaviour therapy as : certain learned responses, or sets of responses of the organism can be considered undesirable or harmful to the organism; or prevent the organism from acquiring certain other responses which would be more beneficial. The therapists assume that this behaviour has been learned, or acquired,

^I am indebted to the 1967 final year students, Sub-Department of Logopedics, University of the Witwatersrand, for this phrase. (A smarty is a small chocolate lentil given as a reward to reinforce a desired response.)

fournal of the South African Logopedic Society, Vol. I5, No. I: December 1968 
according to certain laws, and that behaviour which has been learned can, also by adherence to the principles derived from a study of learning, be unlearned, by being treated in various ways. In this way behaviour can be modified to the benefit of the organism.

Ullmann and Krasner state that:

Behavior modification is the application of the results of learning theory and experimental psychology to the problem of altering maladaptive bchavior. The focus of attention is overt behavior, and, in terms of both the development and change of behaviour, no distinction is made between adaptive and maladaptive responses. ${ }^{6}$

Wolpe, in his Psychotherapy by Reciprocal Inhibition, describes the scope of his text:

In this book a new theory' of psychotherapy is presented... one that is based ne the prowing body of knowledge of the processes by which change is wrought in the behavior of organisms-modern learning theory-the fruit of the efforts of Pavlov, Thorndike, Watson, Tolman, Hull, Skinner and their followers.

He presents the logic of the approach briefly:

Only three kinds of processes are known that can bring about lasting changes in an organism's habit of response to a' given stimulus situation: growth, lesions, ince neurotic bchavior demonstrably originates in learning, it is only to be expected that its elimination will be a matter of unlearning.

In what does treatment consist? Eysenck is of the opinion that:

.. trcatment is in essence a very simple process. In the case of surplus conditioned responses, treatment should consist in the extinction of these responses; in the case of deficient conditioned responses, treatment should consist in the building up of the missing stimulus-response connections. ${ }^{3}$

Ullmann and Krasner say that:

the working behaviorist asks three questions:

(a) What behavior is maladaptive, i.c. what subject behavior should be increased or decreased?

(b) What environmental contingencies currently support the patient's behavior?

(c) What environmental changes, usually reinforcing stimuli, may be manipu-

lated to alter the subject's behavior?

Once we have this framework in mind, it is of relevance for the speech therapist to view the field of speech pathology within it. There are various ways in which the relationship between speech therapy and behaviour therapy can be viewed:

(a) existing speech therapy principles and techniques can be rephrased in learning terminology;

(b) existing behaviour therapy techniques can be used in the treatment of people with communication defects;

(c) learning theory principles can be used in the treatment of people with communication defects.

The third possibility seems to have the widest implications and appears to be the least limiting; some benefit can, however, be derived from a consideration of the other two. To consider the first possibility, we can refer to the work of authors who may or may not be avowed adherents of behaviour therapy.

From his writings, it seems as if Dr. Van Riper can be described as one type of-'ist'-not behaviourist, analyst, semanticist, but therapist. This pragmatic approach allows for many theoretical orientations and, as with any therapy which works; can be interpreted in many ways; however it is probably not assuming too much to view some of his ideas 
as being within a learning framework, to interpret his progressive approximation technique as identical to the behaviour therapists' shaping, or to see cancellation easily transposed to learning terminology. ${ }^{7}$ Brutten and Shoemaker, by using the phrase determining critical stimuli put much of the work we do with parents of young stutterers into a learning theory framework. ${ }^{1}$

To cite another example, Dunlap's negative practice could be rephrased as reactive inhibition. ${ }^{2}$ This example shows that while rephrasing we can do more than practise semantic exercises; we could follow Yates' work where he utilised not only the concept of reactive inhibition but, through massed practice, established conditioned inhibition, i.e. where the habit of not performing the undesired responses was made to replace the habit of performing it. ${ }^{9}$ This type of thinking indicates the way in which rephrasing terminology can give rise to greater and more scientific application than existed before. The value of viewing existing speech therapy principles and techniques from a learning standpoint is that, if they are accepted as such, they can be carried out with more scientific conviction than they have been. If a therapist is to carry out shaping, or establish conditioned inhibition, he should do so with an awareness of all the implications of these procedures, an awareness based on knowledge of learning theory, and one which will take into consideration important factors such as schedules of reinforcement. If he has not got this knowledge, small wonder that the desired pattern of response is soon replaced by the older and stronger incorrect response.

The second way to consider the relationship is by applying existing behaviour therapy techniques to speech therapy cases; the psychologist who is specialising in behaviour therapy techniques considers speech as behaviour, subject to the same laws as any other behaviour. Aberrant speech responses can, they believe, be extinguished or modified in the same way as any other undesirable responses (e.g. phobias, tics and smoking). A survey of the articles in journals such as Behaviour Research and Therapy and in texts on behaviour therapy indicates the interest shown in the field of communication defects. Reports have been given on the utilisation of systematic desensitisation of the anxiety of stutterers, of people with voice defects, or of those suffering from aphasia; much work has been done utilising operant conditioning with non-verbal children and adults; modification of stuttering behaviour has been attempted, using Wolpe's reciprocal inhibition techniques to reduce anxiety, and various other techniques (e.g. aversive conditioning) to alter the actual stuttering response. It can be predicted that, as speech is so overt a series of responses, the modification of defective speech will arouse more and more interest among the behaviour therapists. This must be welcomed by speech therapists, who are always aware of the necessity for, and the benefit to be derived from, co-operation with related specialists. If, however, one would ask that speech therapists using behaviour therapy techniques should have a deeper understanding of its techniques, one could also wish that behaviour therapists would benefit

Fournal of the South African Logopedic Society, Vol. 15, No. I: December 1968 
from the experience of speech therapists, by becoming more knowledgeable about the speech defects with which they wish to work. The speech therapist knows for example, the often harmful effects of teaching a stutterer to inhibit his stuttering; he knows the implication of teaching language, as opposed to teaching speech, to the non-verbal child. This kind of knowledge would be of great practical value to the behaviour therapist, and would serve to make for greater economy in his work with speech or language-handicapped people.

This leads us to the third approach: the awareness that the speech therapist should have a thorough understanding of learning theory. This consideration differs from the other in that it stresses the principles of learning theory, rather than the practices of therapy based on learning theory, practices which are often devised by behaviour- and not by speechtherapists. If we merely accept these practices and apply them, we take over their inherent limitations as well as their advantages. We are being narrowed by the thinking and work of the behaviour therapists who are not necessarily conversant with all the implications of speech and language problems.

Although behaviour therapy is not long out of its infancy it is close to, if not already in, the schools stage. We must be aware of the disadvantages of partisanship - of belonging, for example, to the Skinnerian as opposed to the Hullian school. By virtue of the fact that we have not trained as psychologists, we have a certain distance which allows us to see and, to some extent, to reconcile behaviour therapy viewpoints (just as the psychologist, not orientated to any one particular approach in speech therapy, may have an overview of our field).

Coupled with our knowledge of communication defects, a thorough study of learning theory can place us in a sound position from which to draw up our own theoretical framework, within which we can devise principles and techniques that will help us in our treatment. As with any series of techniques, the use of behaviour therapy can become merely technical and mechanical. It would be unfair to behaviour therapy, and, on a more practical basis, to our cases if, through superficial understanding and application of the techniques, we misuse them, and so cause other workers to become disenchanted with the ideas implicit in this type of therapy. Our understandable anxiety to find keys to aid in the solution. of therapy problems has sometimes led to frenetic hyperactivity, when we try haphazardly to fit any key into the keyhole. We must guard against a tendency to overlook the relationship between key and keyhole; or to attempt too casual a movement of key in the lock, and then to discard this key as not fitting, without giving it time to prove itself the correct one.

In working with people we cannot allow ourselves to become casual. If behaviour therapy is to work, if any therapy is to work, it must be based on a thoughful, scientific, persistent approach. Any approach can become a fad, if we allow it to; it would be more than a pity if we allow 
this to happen with behaviour therapy which could become, if used correctly, a strong and effective force in our work.

\section{Summary}

As behaviour therapy is becoming fashionable, it is important for speech pathologists to ask the question-for us, is behaviour therapy a force or a fad?

This article discusses the way in which speech therapy is influenced by outside trends, and cites, as an example, the developments in stuttering therapy.

Some definitions and descriptions of behaviour therapy are given briefly, and particular reference is made to the work of Wolpe and of Eysenck, and to the review articles of Rachman, and Ullmann and Krasner.

The interest of behaviour therapists in the field of communication disorders is shown by the number of relevant articles in texts and in journals such as Behaviour Research and Therapy which contain reports of the use of techniques such as systematic desensitisation with stutterers, voice cases and aphasics; operant conditioning with non-verbal children and adults, etc. An indication is given that behaviour therapists could benefit from the knowledge of speech therapists, e.g. as regards the dangers of teaching a stutterer to inhibit his stuttering; or the difference between teaching speech and teaching language to the non-verbal child.

The relationship between speech therapy and behaviour therapy is viewed in three ways:

(a) existing speech therapy principles and techniques can be rephrased in learning terminology;

(b) existing behaviour therapy techniques can be used in the treatment of people with communication defects;

(c) learning theory principles can be used in the treatment of people with communication defects.

The third possibility is seen as having the widest implications.

It would be unfair to behaviour therapy and on a more practical basis, to our cases if, through superficial understanding and application of the techniques we misuse them and so cause other workers to become disenchanted with the ideas implicit in this type of therapy. In working with people we cannot allow ourselves to become casual. Therapy must be based on a thorough, scientific, persistent approach. Behaviour therapy can become, if used correctly, a valuable force in our work.'

\section{Opsomming}

Omdat gedragsterapie deesdae mode 'geword het, is dit belangrik vir die spraakpatoloog om homself die vraag te vra, is gedragsterapie 'n gemotiveerde krag of bloot 'n gier?

Ons vind in hierdie artikel 'n bespreking oor die invloed van neigings van buite, op spraakterapie, en stel as voorbeeld die ontwikkeling op die

Fournal of the South African Logopedic Society, Vol. 15, No. I: December 1968 
gebied van hakkelterapie. Verskeie definisies en beskrywings van gedragsterapie word kortliks gegee en daar word spesifiek na die werk van Wolpe, Eysenck, Rachman, Ullmann en Krasner, verwys.

Die groot aantal toepaslike artikels wat die afgelope tyd verskyn het, toon die belang van gedragsterapeute in die veld van kommunikasieafwykings. As voorbeeld word Behaviour Research and Therapy, genoem, Hierdie werk bevat verslae oor die gebruik van tegnieke, soos bv. sistematiese weerstandsopbou met hakkelaars, disfonie en afatiese gevalle; operante kondisionering met nie-verbale kinders en volwassenes, ens.

Dit blyk ook dat gedragsterapeute baat by die kennis van spraakterapeute, veral met betrekking tot die gevare wat bestaan om bv. 'n hakkelaar te leer om sy hakkel te inhibeer; of die verskil tussen die leer van spraak en die leer van taal aan die nie-verbale kind.

Die verbouding tussen spraakterapie en gedragsterapie word op drie wyse beskou:

(a) bestaande spraakterapeutiese beginsels en tegnieke kan herbenoem word volgens die ,leer'-terminologie;

(b) bestaande gedragsterapietegnieke kan gebruik word in die behandeling van mense met kommunikasieafwykings;

(c) leerteoriebeginsels kan gebruik word in die behandeling van mense met kommunikasieaf wykings.

Hierdie laasgenoemde moontlikheid word gesien as dié met die grootste implikasies.

Dit sal onregverdig teenoor gedragsterapie, en op meer praktiese basis, teenoor ons gevalle wees as ons, deur 'n oppervlakkige begrip en verkeerde toepassing van tegnieke, ander se belangstelling laat kwyn.

Ons mag nie onverskillig wees wanneer ons met mense werk nie. Terapie moet gebasseer wees on 'n deeglike, deurtastende en wetenskaplike benadering. Gedragsterapie kan, wanneer dit korrek toegepas word, 'n belangrike bydrae by ons werk lewer.

\section{REFERENCES}

I. Brutten, E. J. and Shoemaker, D. I. $(1967)$ : The Modification of Stuttering, Prentice Hall Inc., Englewood Cliffs, N.J.

2. Dunlap, K. (1932): Habits: Their Making and Unmaking. Liveright Inc, N.Y.

3. Eysenck, H. J. (Ed.) (1960): Behaviour Therapy and the Neuroses. Pergammon Press, Oxford.

4. Marks, M. (1966): Stuttering Viewed as a Sequence of Responses. Paper' presented at the International Seminar on Stuttering and Behavior Therapy, Carmel, California.

5. Rachman, S. J. (1963): Introduction to Behaviour Therapy, Behaviour Research and Therapy. 1, 3-16.

6. Ullman, L. P. and Krasner, L. (1965): Case Studies in Behavior Modification. Holt, Rinehart and Winston Inc.

7. Van Riper, C. (1963): Speech Correction: Principles and Methods. (4th Edition.) Prentice Hail Inc., Englewood Cliffs, N.J.

8. Wolpe, J. (1958): Psvchotherapy by Reciprocal Inhibition. Stanford University Press, Stanford, Calif. and Witwatersrand University Press, Johannesburg.

9. Yates, A. J. (1958): The Application of Learning Theory to the Treatment: of Tics. Journal of Abnormal and Social Psychology. 56, I75-182. 